\title{
Influence of Management Behavior on the Skilled Labor Migrations' Unsafe Behavior
}

\author{
Shu Chen ${ }^{1,2}$, Yue Wang ${ }^{1}$, Yuzhu Yang ${ }^{1}$, Xiazhong Zheng ${ }^{1,2}$ \\ ${ }^{1}$ Hubei Key Laboratory of Construction and Management in Hydropower Engineering, \\ China Three Gorges University (P.R. China) \\ ${ }^{2}$ College of Hydraulic \& Environmental Engineering, China Three Gorges University (P.R. China) \\ cbenshu@wbu.edu.cn,836078556@qq.com,1098799146@qq.com,zhengxz@126.com
}

Received: January 2015

Accepted: May 2015

\section{Abstract:}

Purpose: The purpose of this study was to summarize safety management of manager into two aspects (design behavior and management behavior) and to figure out the different impact these two behaviors might have.

Design/methodology/approach: In order to verify the reasonableness of the assumptions, expert investigation was used by the means of semi-structured interview. And the Structural Equation Modeling (SEM) is estimated using 850 individual questionnaire responses from five companies in the form of Likert-type scale. What's more, taking the measurement error causing by common method biases into consideration, Univariate Testing was taken to measure the deviation effect.

Findings: The results obtained with this description showed that certain measures should be adopt by managers to develop purposively the safety knowledge and safety motivation of the skilled labor migrations (SLMs).

Research limitations/implications: Unsafe behavior, which has aroused extensive concern in recent years, is the subject of many safety management studies. However, there have not been any studies on the influence of management behavior on SLMs unsafe behavior. 
Practical implications: As the unsafe behavior of SLMs is the most important accident reason, this paper may help reduce the incidence of accidents.

Originality/value: The conclusion that managers' management behavior can definitely affect skilled labor migrations' unsafe behavior and skilled labor migrations' internal factors can also influence their own unsafety behavior in turn will certainly provide the beneficial reference views on the management behavior.

Keywords: unsafe behavior, management behavior, skilled labor migrations, SEM

\section{Introduction}

With individual project construction's subcontracting to other construction team, skilled labor migrations (SLMs) is becoming the most important construction factor in the engineering construction (EC). Due to the highly risky working place, low level of education, poor technical quality, safety consciousness and poor self-defense capability, casualties continue to occur (Chen, Yu, Zheng \& Chen, 2014). According to the accident investigation, the unsafe behavior of SLMs is the most important accident reason in EC (Chen, Yu \& Wu, 2014). Thus, SLMs' unsafe behavior management has been recognized as the fundamental way for the prevention and conformity of EC (Cao \& Xu, 2010).

Many studies and literatures have confirmed that management factors have a significant impact on human's unsafe behavior. The factors of organization management such as pressure have an impact on the accident through individual behavior(Oliver, Cheyne, Tomas \& Cox, 2002). Positive safety communication and management attitude could promote members of the organization to improve the level of mutual trust (Kath, Magley \& Marmet, 2010). Under this kind of mutual trust, the choice of motivation of the organization's employees for safety work behavior could be significantly improved. However, management factors are of great many that can influence the unsafe behavior of the SLMs, such as safety procedures, policies and systems, safety training, safety supervision, communication, etc., whose influence may differ from the unsafe behavior of the SLMs (Zheng, Chen, Chen \& Hu, 2011). Safety procedures and safety training can provide the necessary safety knowledge for the SLMs, which meant a lot for preventing the selections of insecurity behavior of the SLMs because of ignorance. However, they may not be effective for the prevention of unsafe behavior intentionally chosen. Policies and systems, safety supervision, communication, etc. can affect the safety motivation, which may meant a lot for preventing the choices of unsafe behavior of SLMs because of intention. However, they may not be effective for the prevention of unsafe behavior because of ignorance (Cao, Li \& Li, 2011). 
Influence on single or partial management factors of people's unsafe behavior, which has gained increasingly greater importance in recent years, is one of the subjects of many studies. However, systematic study of the various management factors on the human impact of unsafe behavior remains scarce. What's more, there haven't been any studies researching on the influence on the SLMs' unsafe behavior of a variety of management factors. Yet, in order to promote good management of the SLMs' managers on unsafe behavior, it is of great significance to study on the characteristics on which various safety managements may influence. Therefore, this study will summarize various EC safety management into two aspects (design behavior and managerial behavior of manager), and empirically research on the different impact path and characteristics which these two different behavior of manager effects on SLMs' unsafe behavior. Eight hypotheses will be presented in this paper about the relationships among design behavior and managerial behavior of manager as well as safety knowledge, safety motivation, compliance behavior and participatory behavior of SLMs. Research variables and measurement scale will be established by referencing related research widely. The SLMs in Xiangjiaba Hydropower Station will be selected as the respondents to answer the questionnaire designed in the form of Likert-type scale. On the base of that, theoretical model will be established using SEM to verify the correctness of assumptions. The eight hypotheses will be tested by variables statistics, reliability analysis, and model testing, which will certainly provide a new perspective for further research on managerial behavior. In summary, the hypotheses verified in the following part of this paper will certainly provide the beneficial reference views on the management behavior.

\section{Influence Analysis}

Unsafe behavior of SLMs is influenced by instinct characteristics and managerial behavior. The combined effect of these two factors can create different benefits.

\subsection{Instinct Characteristics}

The unsafe behavior is generally the results chosen by the SLMs' conscious or unconscious. According to the studies mentioned above, safety knowledge and safety motivation can both be used to describe the unsafe behavior of SLMs. Safety knowledge describes the safety awareness status and determines whether the SLMs are able to recognize the security of their own behavior when they choose their actions. Safety motive describes the safety awareness state when SLMs are in the choice of action, which determines whether the SLMs are willing to choose safe behavior. Under normal circumstances, the manager does not directly determine the behavior of the SLMs. However, they can influence or control the SLMs indirectly through 
their own behavior. Various management practices managers implemented on the SLMs are all achieved by affecting safety knowledge and motivation of the SLMs.

\subsection{Management Performance}

There exist a variety of managerial behavior factors that can influence people's unsafe behavior. Some research institutions and scholars have classified and summarized management behavior affecting people's unsafe behavior. The International Atomic Energy Agency (IAEA) described the management behavior and summarized them into 6 aspects (including decision-making, planning, organization, management, clarify the ambiguity, and work related or unrelated activities). However, many scholars summarized all kinds of management behavior into two aspects: firstly, a suitable method for designing security processes and procedures should be adopt; and secondly, the process control for operations should be effective (Kirwan, 2007).

Based on the studies mentioned above, manager behavior that influences the SLM's unsafe behavior can be divided into two aspects (design behavior and management behavior). Design behavior provides experience, knowledge, and action plans of SLMs by making various safety norms, procedures, plans, programs and systems for the SLMs. Management behavior is the results that managers influence the SLMs' behavior directly in accordance with their design behavior. The design behavior of manager is the foundation for their implementing management behavior. Hypothesis is put forward according to above analysis.

$H_{1}$ Design behavior of managers has a significant positive impact on their management behavior.

\subsection{Management Influence}

Design behavior of the managers can influence the behavior of the safety knowledge of the workers. Safety management is an action using organizational approach to manage safety, which is the important factors influencing the unsafe behavior of employees (Cacciabue \& Vella, 2010). The development of safety systems and procedures could provide necessary safety knowledge for employees, which has been confirmed to be the common management factors of predicting the unsafe behavior of the employees (Vinodkumar \& Bhasi, 2011). What's more, various safety management practices can be divided into two categories including the project manager behavior (mainly setting up for employees or providing a safe environment and objectives procedures) and the security management behavior (mainly 
guiding and supervising daily work activities of employees) (Aksorn \& Hadikusumo, 2008). Hypothesis is put forward according to above analysis.

$\mathrm{H}_{2}$ Design behavior of manager has a significant positive impact on safety knowledge of the SLMS.

Management behavior of managers can affect the safety motivation of employees. Creating a safe atmosphere and strengthening the supervision are important factors affecting staff's autoreport behavior (Probst \& Estrada, 2010). The higher commitment the manager can provide, the more security responsibility the employee feel, the less unsafe behavior they will choose, and thus a higher level of safety performance they will act (Yule, Flin \& Murdy, 2007). Hypothesis is put forward according to above analysis.

$\mathrm{H}_{3}$ Management behavior of managers has a significant positive impact on the safety motivation of the SLMS.

Management behavior of managers can also affect the safety knowledge of workers. Inadequate training is the main factor causing the malpractice (Vredenburgh, 2002). The most important purpose of safety management is to adopt some management to influence employees' safety attitudes and behavior. Empirical research showed that training is the most important management factor affecting employee's safety knowledge and motivation (Vinodkumar \& Bhasi, 2010). Hypothesis is put forward according to above analysis.

$\mathrm{H}_{4}$ Management behavior of managers has a significant positive impact on safety knowledge of the SLMS.

As for the unsafe behavior of employees, it is the structural behavior and interactive behavior that should be measured. Structural behavior measures the extent of employees involving in organizing security activities. Interactive behavior measures the extent of employees mutual influencing. Meanwhile, it measures the communication atmosphere their managers with the surrounding colleagues in their daily work (Cheyne, Cox, Oliver \& Tomas, 1998). The unsafe behavior of the staff has been measured using the security compliance behavior and participatory behavior. Security compliance behavior measures the extent of the employees' compliancing with regulations and working in accordance with the provisions of the safety procedures. Security participatory behavior measures the extent of the employees' helping 
working partners, improving the degree of initiative as well as improving the level of safety in the workplace (Neal, Griffin \& Hart, 2000). Structural behavior and interactive behavior are similar with compliance behavior and participatory behavior. Certainly, in a recent study, three indicators have been applied to measure employees' unsafe behavior, but they are mainly developed according to the two indicators mentioned above (Larsson, Pousette \& Törner, 2008; Pousette, Larsson \& Törner, 2008). Given this, compliance behavior and participatory behavior can be applied to describe and measure the unsafe behavior of the SLMs.

As previously mentioned, insecurity behavior is the results choosing intentionally or unintentionally by the SLMs according to the circumstances. Their behavior is inevitably affected by their own internal factors, namely affected by their safety knowledge and safety motivation. The risk perceiving of employees is one of the inherent factors affecting their choice of unsafe behavior (Rundmo, 2000). The level of behavior risk of workers can be effectively reduced by raising risk awareness of workers (Inoue, Gotoh, Ishigaki \& Hasegawa, 1999). Due to the fact that the influence of the safety motivation and knowledge is obvious, hypothesis is put forward.

$\mathrm{H}_{5}$ Safety knowledge of SLMs has a significant positive impact on the participatory behavior of SLMS.

$H_{6}$ Safety knowledge of SLMs has a significant positive impact on the compliance behavior of SLMS.

$\mathrm{H}_{7}$ Safety motivation of SLMs has a significant positive impact on the participatory behavior of SLMS.

$H_{8}$ Safety motivation of SLMs has a significant positive impact on the compliance behavior of SLMS.

The rationality of these hypotheses can also be confirmed by expert investigation. Mainly conducted semi-structured interviews, the content of the investigation are mainly related to the reasonableness of the above assumptions. Five scholars and 10 senior managements are involved in the investigation. They are long to be engaged in EC safety management research. The findings showed that the vast majority of those respondents support the above hypothesis. The theoretical model of these hypotheses is shown in Figure 1. 


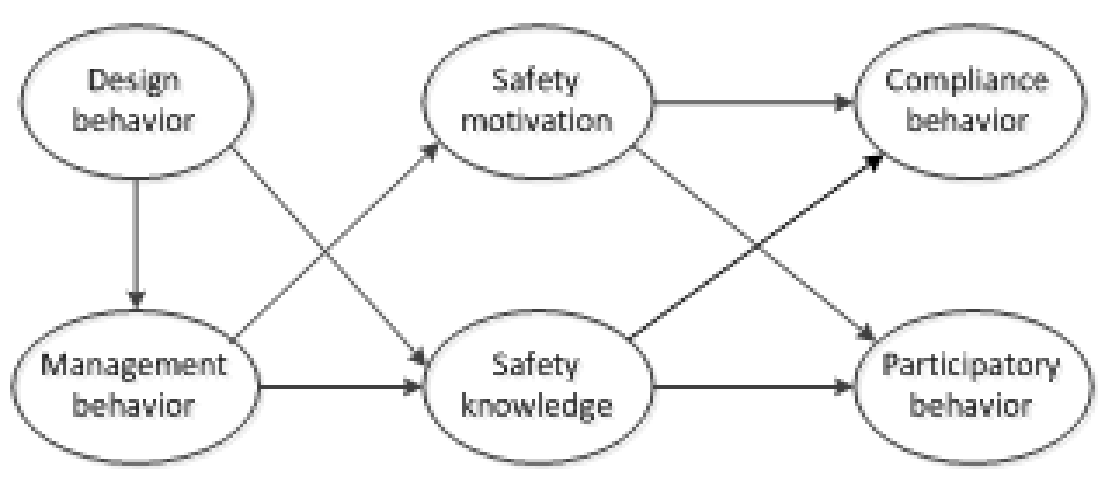

Figure 1. Path Diagram of the Theoretical Model

\section{Methods}

\subsection{Assessment Measures}

In order to determine the variables measurement scale in this study, related research was widely referenced in accordance with the purpose and characteristic. Three variables in the working system (safety, safety regulations and policy system) were used to measure design behavior. And four variables (education training, safety supervision, communication and management commitment) were applied to measure management behavior. Besides, three entries were used to measure the safety of the system, four for the safety regulations and five for the policy system. Four specific entries were used to measure the education training, three for the safety supervision, six for the communication and four for the manager commitment. In addition, four entries were adopted for safety knowledge, five for safety motivation, four for compliance behavior and participatory behavior. The details are represented in the Table1. 


\begin{tabular}{|c|c|c|}
\hline Variable & Measuring entry & Main references \\
\hline $\begin{array}{l}\text { Design } \\
\text { behavior }\end{array}$ & $\begin{array}{l}\text { Working system security } \\
\text { Safety procedures } \\
\text { Policy and system }\end{array}$ & \multirow{2}{*}{$\begin{array}{l}\text { Meyer \& Allen, } 1984 \\
\text { Hale, Heming, Carthey \& Kirwan, } 1997 \\
\text { Matthews, Gallus \& Henning, } 2011 \\
\text { Chen, Yu \& Zheng, } 2014 \\
\text { O'Connor, O'Dea, Kennedy \& Buttrey, } 2011\end{array}$} \\
\hline $\begin{array}{c}\text { Management } \\
\text { behavior }\end{array}$ & $\begin{array}{l}\text { Educational training } \\
\text { Safety supervision } \\
\text { Communication } \\
\text { Managers' commitment }\end{array}$ & \\
\hline $\begin{array}{c}\text { Safety } \\
\text { knowledge }\end{array}$ & $\begin{array}{c}\text { Procedures or standards } \\
\text { Machinery and equipment operations } \\
\text { Working Perception } \\
\text { Risk Perception }\end{array}$ & \multirow{4}{*}{$\begin{array}{l}\text { Lu \& Yang, } 2011 \\
\text { Varonen \& Mattila, } 2000 \\
\text { Coyle, Sleeman \& Adams, } 1996\end{array}$} \\
\hline $\begin{array}{c}\text { Safety } \\
\text { motivation }\end{array}$ & $\begin{array}{c}\text { The satisfaction to workplace } \\
\text { Support others' work } \\
\text { Implementation rate of safe work practices } \\
\text { The attitude towards others' unsafe behavior } \\
\text { Enthusiasm }\end{array}$ & \\
\hline $\begin{array}{c}\text { Compliance } \\
\text { behavior }\end{array}$ & $\begin{array}{c}\text { Compliance with procedures or standards } \\
\text { Using safety supplies } \\
\text { Engaged in skilled work } \\
\text { Conditions of complying with the rules and } \\
\text { procedures }\end{array}$ & \\
\hline $\begin{array}{c}\text { Participatory } \\
\text { behavior }\end{array}$ & $\begin{array}{c}\text { Engaged in non-duty job } \\
\text { Helping others } \\
\text { Communication with superiors } \\
\text { Upgrading working safety }\end{array}$ & \\
\hline
\end{tabular}

Table 1. Research Variables and Measurement Scale

\subsection{Method Designs}

First of all, pre-survey was taken using the scales designed on the basis of practical situation. Then, the initial analysis as well as optimization and improvement of the scale was advanced using the data collected through the pre-survey. Last, formal scale could be determined after the work mentioned above. Besides, in order to obtain the accurate and effective data during the investigation, several measures were adopted. For example, Likert-type scale was used to design the questionnaire, two stage method was adopted to collect the data, SPSS 17.0 was applied to analyze reliability and validity of the entire scale, AMOS 7.0 was applied to analyze the relationship between the variable, and SEM was set to assess the fit of and compare the skilled labor migrations' unsafe behavior model. What's more, taking the measurement error causing by common method biases into consideration, Univariate Testing was taken to measure the deviation effect.

\subsection{Data Collection and Sample Analysis}

Designed in the form of Likert-type scale, measurement for the questionnaire was divided into five classes (totally inconsistent, partly consistent, basically consistent, mostly consistent and totally consistent). Recording 1 point for totally inconsistent, 5 for totally consistent and the remaining points were followed by analogy. The SLMs in Xiangjiaba Hydropower Station was 
selected as the respondents to answer the questionnaire described in neutral. Besides, the questionnaire was handed over in random and filled willingly. Moreover, the result of the questionnaire was not distinguished between right and wrong but only used for research, which was attached at the bottom of the questionnaire.

At meantime, two stage methods were adopted to collect the data. One construction team was selected at the first stage, and four construction teams were chosen at the second stage to answer the question put forward at the questionnaire such as digging in, transportation, geological survey and so on. The results are showed in the Table 2.

\begin{tabular}{|c|c|c|c|c|c|}
\hline $\begin{array}{c}\text { The number of } \\
\text { questionnaires }\end{array}$ & $\begin{array}{c}\text { Number of } \\
\text { questionnaires } \\
\text { recovered }\end{array}$ & $\begin{array}{c}\text { Recovery } \\
\text { rate }\end{array}$ & $\begin{array}{c}\text { Effective number of } \\
\text { questionnaires }\end{array}$ & $\begin{array}{c}\text { Valid } \\
\text { recovery } \\
\text { rate }\end{array}$ & $\begin{array}{c}\text { Invalid number of } \\
\text { questionnaires }\end{array}$ \\
\hline 850 & 778 & $91.53 \%$ & 691 & $81.29 \%$ & 87 \\
\hline
\end{tabular}

Table 2. List of the research questionnaires recovery profile

Taking the measurement error caused by common method biases into consideration, Univariate Testing was taken to measure the deviation effect. Through the analysis of the factors not rotated, the explained variance of the deposition of the first principal component was 0.29. Furthermore, the variance explained of the five factors above was 0.69 . It could be determined that the common method bias does not have a serious impact on the path coefficients between the variables.

\section{Results and Discussion}

This section presents the results of the statistical analysis of the data obtained from the survey. First, SPSS 17.0 and AMOS 7.0 software will be applied for statistical processing of the data collected, including reliability and validity analysis on scale as well as confirmatory factor analysis. Then the model will be tested consisting of the degree of absolute adaptation and the degree of increment adaptation. On the base of that, the eight hypotheses were tested.

\subsection{Reliability Analysis}

The SPSS 17.0 was used to analyze reliability and validity of the entire scale. The fact that the value of Cronbach's a was 0.974 indicated the high reliability of the scale. Reliability analysis of each subscale showed that the a coefficients were all more than 0.800 including design behavior, management behavior, safety knowledge, safety motivation, compliance behavior, participatory behavior, working system security, safety procedure, policy and system, 
educational training, safety supervision, communication, managers' commitment. Besides, the scores of each variable and the overall correlation coefficient were in an appropriate range. Therefore, the scale's consistency and reliability was suitable. The data of the variables' basic statistics and reliability analysis in the survey are shown in Table 3.

\begin{tabular}{|c|c|c|c|c|c|}
\hline Variable & Measuring entry & Mean & Variance & $\begin{array}{l}\text { The overall } \\
\text { correlation coefficient }\end{array}$ & Cronbach's a \\
\hline \multirow{3}{*}{$\begin{array}{l}\text { Design } \\
\text { behavior }\end{array}$} & Working system security & 3.541 & 1.223 & 0.808 & \multirow{3}{*}{0.915} \\
\hline & Safety procedure & 3.543 & 1.345 & 0.829 & \\
\hline & Policy and system & 3.574 & 1.285 & 0.847 & \\
\hline \multirow{4}{*}{$\begin{array}{l}\text { Management } \\
\text { behavior }\end{array}$} & Educational training & 3.895 & 0.751 & 0.645 & \multirow{4}{*}{0.936} \\
\hline & Safety supervision & 3.787 & 1.418 & 0.933 & \\
\hline & Communication & 3.752 & 1.082 & 0.931 & \\
\hline & Managers' commitment & 3.811 & 1.200 & 0.938 & \\
\hline \multirow{4}{*}{$\begin{array}{c}\text { Safety } \\
\text { knowledge }\end{array}$} & Procedures or standards & 3.753 & 1.795 & 0.790 & \multirow{4}{*}{0.909} \\
\hline & Machinery and equipment operations & 3.885 & 1.543 & 0.792 & \\
\hline & Working Perception & 3.900 & 1.554 & 0.779 & \\
\hline & Risk Perception & 3.731 & 1.557 & 0.801 & \\
\hline \multirow{5}{*}{$\begin{array}{l}\text { Safety } \\
\text { motivation }\end{array}$} & The satisfaction to workplace & 4.032 & 1.339 & 0.789 & \multirow{5}{*}{0.906} \\
\hline & Support others' work & 3.820 & 1.197 & 0.774 & \\
\hline & $\begin{array}{c}\text { Implementation rate of safe work } \\
\text { practices }\end{array}$ & 3.754 & 1.279 & 0.800 & \\
\hline & $\begin{array}{c}\text { The attitude towards others' unsafe } \\
\text { behavior }\end{array}$ & 3.802 & 1.597 & 0.765 & \\
\hline & Enthusiasm & 3.492 & 1.115 & 0.684 & \\
\hline \multirow{4}{*}{$\begin{array}{l}\text { Compliance } \\
\text { behavior }\end{array}$} & Compliance with procedures or standards & 3.661 & 1.375 & 0.762 & \multirow{4}{*}{0.898} \\
\hline & Using safety supplies & 3.794 & 1.581 & 0.775 & \\
\hline & Engaged in skilled work & 3.745 & 1.449 & 0.813 & \\
\hline & $\begin{array}{l}\text { The conditions of complying with the } \\
\text { rules and procedures }\end{array}$ & 3.491 & 1.219 & 0.737 & \\
\hline \multirow{4}{*}{$\begin{array}{c}\text { Participatory } \\
\text { behavior }\end{array}$} & Engaged in non-duty job & 3.852 & 1.621 & 0.718 & \multirow{4}{*}{0.907} \\
\hline & Helping others & 3.781 & 1.695 & 0.814 & \\
\hline & Communication with superiors & 3.788 & 1.637 & 0.815 & \\
\hline & Upgrading working safety & 3.637 & 1.561 & 0.812 & \\
\hline
\end{tabular}

Table 3. Variables Statistics and Reliability AnalysisConfirmatory factor analysis

Confirmatory factor analysis is a test method above a particular theoretical perspective or conceptual framework. It assesses whether the econometric models derived by the theoretical ideas or concepts are appropriate, and thus, the appropriateness and authenticity of model's construct validity can be test before the analysis. The standard factor loadings and its values of $T$ Inspection of the measuring entries were shown in Table 4 after confirmatory factor analysis by software AMOS 7.0. To estimate the variance of the variables liberally, unstandardized path coefficient of measurement entry noted * was set as 1 in every variable. These measurement 
entries needn't do the path coefficient significant test. Therefore, standard errors are not exist and the same as $\mathrm{T}$ inspection. The analysis data showed that the standard factor loadings of every measuring entry are greater than, or close to 0.700 . The non-fixed measuring entry are also much larger than 0.050 . The threshold of the significant level was 1.960 indicating well explain for the measured variables.

\begin{tabular}{|c|c|c|c|}
\hline Variable & Measuring entry & $\begin{array}{l}\text { Standard factor } \\
\text { loadings }\end{array}$ & $\begin{array}{l}\text { The values of T } \\
\text { Inspection }\end{array}$ \\
\hline \multirow{3}{*}{$\begin{array}{l}\text { Design } \\
\text { behavior }\end{array}$} & Working system security & 0.843 & 29.681 \\
\hline & Safety procedures & $0.889 *$ & \\
\hline & Policy and system & 0.921 & 33.822 \\
\hline \multirow{4}{*}{$\begin{array}{c}\text { Management } \\
\text { behavior }\end{array}$} & Educational training & $0.713^{*}$ & \\
\hline & Safety supervision & 0.971 & 22.388 \\
\hline & Communication & 0.970 & 22.321 \\
\hline & Managers' commitment & 0.967 & 22.327 \\
\hline \multirow{4}{*}{$\begin{array}{c}\text { Safety } \\
\text { knowledge }\end{array}$} & Procedures or standards & $0.851 *$ & \\
\hline & Machinery and equipment operations & 0.845 & 29.462 \\
\hline & Working Perception & 0.856 & 30.021 \\
\hline & Risk Perception & 0.841 & 29.091 \\
\hline \multirow{5}{*}{$\begin{array}{l}\text { Safety } \\
\text { motivation }\end{array}$} & The satisfaction to workplace & $0.861^{*}$ & \\
\hline & Support others' work & 0.791 & 26.513 \\
\hline & Implementation rate of safe work practices & 0.813 & 27.643 \\
\hline & The attitude towards others' unsafe behavior & 0.842 & 29.500 \\
\hline & Enthusiasm & 0.724 & 22.971 \\
\hline \multirow{4}{*}{$\begin{array}{c}\text { The } \\
\text { compliance } \\
\text { behavior }\end{array}$} & Compliance with procedures or standards & 0.787 & 23.201 \\
\hline & Using safety supplies & 0.814 & 24.367 \\
\hline & Engaged in skilled work & 0.892 & 28.232 \\
\hline & $\begin{array}{l}\text { The conditions of complying with the rules and } \\
\text { procedures }\end{array}$ & $0.800 *$ & \\
\hline \multirow{4}{*}{$\begin{array}{l}\text { Participatory } \\
\text { behavior }\end{array}$} & Engaged in non-duty job & 0.835 & 27.710 \\
\hline & Helping others & 0.851 & 28.651 \\
\hline & Communication with superiors & 0.851 & 28.926 \\
\hline & Upgrading work safety & $0.829 *$ & \\
\hline
\end{tabular}

Table 4. Results of Confirmatory Factor Analysis

\subsection{Model Testing and Calculation}

The degree of absolute adaptation of the integrated model was measures by $\chi^{2} / d f$, RMSEA, GFI and SRMR. At meantime, the degree of increment adaptation was measured by NFI, NNFI and CFI. The models an acceptable standard fit index and their criterion shown in Table 5 indicating a good fitness between theoretical models and the actual data, a great significant basic adaptation indicators of estimation and a great convergence. 


\begin{tabular}{|l|c|c|c|c|c|c|c|}
\hline Fit Index & $\chi^{2} /$ df & RMSEA & GFI & SRMR & NFI & NNFI & CFI \\
\hline Statistics & 3.857 & 0.071 & 0.911 & 0.043 & 0.948 & 0.944 & 0.952 \\
\hline Criterion & $2<\chi^{2} / d f<5$ & $<0.080$ & $>0.900$ & $<0.080$ & $>0.900$ & $>0.900$ & $>0.900$ \\
\hline
\end{tabular}

Table 5. Goodness-of-Fit Indices of the Model

Path coefficients among theoretical models calculated on the basis of the sample data were shown in Figure 2. And $* * *$ stands for $\mathrm{P}<0.001$. Figure 2 showed that the path coefficients were notable in the level of $P<0.001$ among design behavior $==>$ management behavior, management behavior $==>$ Safety knowledge, management behavior safety motivation, safety motivation $==>$ the compliance behavior and safety knowledge participatory behavior.

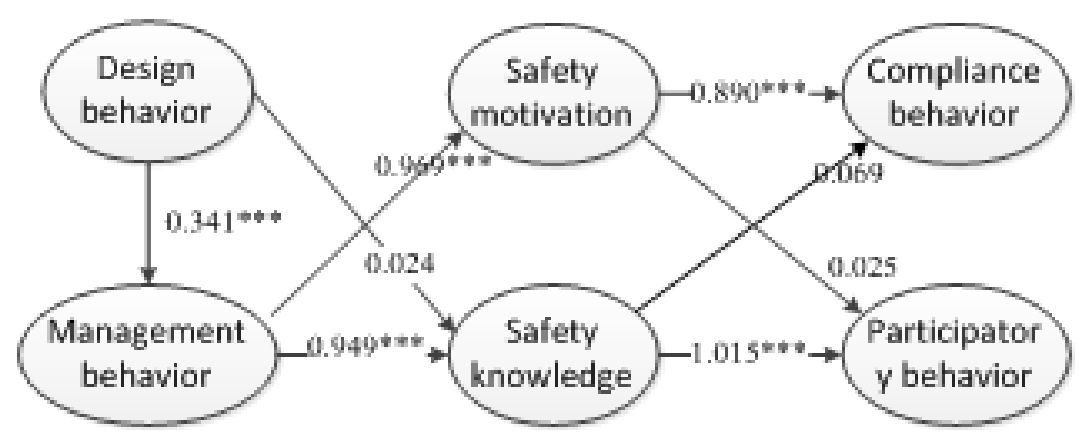

Figure 2. Research Variables and Measurement Scale

\subsection{Hypothesis Testing and Offending Estimates}

- $\mathrm{H}_{1}$ is proper. It indicates that managers' design behavior has a significant positive impact on management behavior.

- $\mathrm{H}_{2}$ is not passing the inspection. The possible reason is that only by using management behavior can managers' design behavior have a significant impact on the safety knowledge.

- $\mathrm{H}_{3}$ is appropriate. It shows that managers' management behavior has an obvious positive effect on safety motivation.

- $\mathrm{H}_{4}$ is proper. The safety knowledge is proved to be significantly effected by managers' management behavior.

- $\mathrm{H}_{5}$ is appropriate which indicates that safety knowledge has a significant positive impact on participatory behavior. 
- $\mathrm{H}_{6}$ is not passing the inspection. The possible reason is that the SLMs who master safety knowledge well are easy to build a "self-righteous" working procedures or rules through their learnings on the job, thus not consisting with work procedures, standards, procedures offered by managers.

- $\mathrm{H}_{7}$ is not passing the inspection. Probably due to the fact that the SLMs who possess higher safety motivation doesn't wish to help others or communicate with others.

- $\mathrm{H}_{8}$ is right since the fact that compliance behavior is proved to be significantly effected by safety motivation.

Path coefficients of the theoretical model and hypotheses test are shown in Table 6 . Removing the above path not passing inspection, the modified model also has an excellent overall degree of adaption, and path coefficients among variables are roughly equal.

\begin{tabular}{|c|c|c|c|c|}
\hline $\begin{array}{l}\text { The relationship between } \\
\text { variables }\end{array}$ & $\begin{array}{l}\text { Standardized path } \\
\text { coefficient }\end{array}$ & Value of $P$ & Assumptions & Test results \\
\hline $\begin{array}{c}\text { Design behavior } \\
\downarrow \\
\text { Management behavior }\end{array}$ & 0.341 & 0.000 & $\mathrm{H}_{1}$ & Pass \\
\hline $\begin{array}{c}\text { Design behavior } \\
\downarrow \\
\text { Safety knowledge }\end{array}$ & 0.024 & 0.161 & $\mathrm{H}_{2}$ & No Pass \\
\hline $\begin{array}{c}\text { Management behavior } \\
\downarrow \\
\text { Safety motivation }\end{array}$ & 0.969 & 0.000 & $\mathrm{H}_{3}$ & Pass \\
\hline $\begin{array}{c}\text { Management behavior } \\
\downarrow \\
\text { Safety knowledge }\end{array}$ & 0.949 & 0.000 & $\mathrm{H}_{4}$ & Pass \\
\hline $\begin{array}{c}\text { Safety knowledge } \\
\downarrow \\
\text { Participatory behavior }\end{array}$ & 1.015 & 0.000 & $\mathrm{H}_{5}$ & Pass \\
\hline $\begin{array}{c}\text { Safety knowledge } \\
\text { The compliance behavior }\end{array}$ & 0.069 & 0.336 & $\mathrm{H}_{6}$ & No Pass \\
\hline $\begin{array}{c}\text { Safety motivation } \\
\downarrow \\
\text { Participatory behavior }\end{array}$ & 0.025 & 0.690 & $\mathrm{H}_{7}$ & No Pass \\
\hline $\begin{array}{c}\text { Safety motivation } \\
\downarrow \\
\text { The compliance behavior }\end{array}$ & 0.890 & 0.000 & $\mathrm{H}_{8}$ & Pass \\
\hline
\end{tabular}

Table 6. Path Coefficients of the Theoretical Model and Hypotheses Test 


\section{Conclusions and Contributions}

This paper summarized various EC safety management into two aspects (design behavior and managerial behavior of manager), and empirically researched on the different impact path and characteristics which these two different behavior of manager effects on SLMs' unsafe behavior. Eight hypotheses were presented. And they were ultimately tested by variables statistics and reliability analysis, confirmatory factor analysis as well as model testing and calculation. On the basis of the relevant literatures and dissertate mentioned above, three clear conclusions are stated as follows:

- Managers' management behavior has a significant positive impact on SLMs' safety knowledge and safety motivation. It is the direct management factor affecting choice of SLMs to unsafe behavior.

- Managers' design behavior has a significant positive impact on management behavior, but it must be accompanied by the necessary management behavior to affect SLMs' safety knowledge or motivation.

- SLMs' safety motivation has a significant positive impact on the compliance behavior. SLMs' safety knowledge has a significant positive impact on participatory behavior. Specifically, SLMs' compliance behavior is mainly affected by safety motivation. But SLMs' participatory behavior is mainly affected by safety knowledge.

Although the results of the study can effectively provide a correct guidance for managers to guide SLM's behavior to reduce accidents, the study still remains some drawbacks. One of the most important limitations to be highlighted is that SLMs selected to fill in the questionnaire were not classified appropriately according to their workplace due to both the time and funding limitations of this study. Second, management behavior, which has been divided into design behavior and management behavior, has not been classified into specific acts In a further improved research, SLMs' behavior will certainly be regiment according to their workplace, and so does management behavior.

\section{Acknowledgements}

Supported by the National Natural Science Foundation of China (No.51379110) and the Open Foundation of Hubei Key Laboratory of Construction and Management in Hydropower Engineering (No.2014KSD08). 


\section{References}

Aksorn, T., \& Hadikusumo B.H.W. (2008). Critical success factors influencing safety program performance in Thai construction projects. Safety Science, 46(4), 709-727. http://dx.doi.org/10.1016/j.ssci.2007.06.006

Cacciabue, P.C., \& Vella, G. (2010). Human factors engineering in healthcare systems: The problem of human error and accident management. International Journal of Medical Informatics, 79(4), e1-e17. http://dx.doi.org/10.1016/j.ijmedinf.2008.10.005

Cao, Q., Li, K., \& Li, J. (2011). Impact of Manager's Behavior on Coalminer's Unsafe Behavior. Journal of Management Science, 24(6), 69-78.

Cao Q-R., \& Xu, Z-Q. (2010). The behavioral causation chain of coal production accidents and its prevention and control measures. China Safety Science Journal, 20(9), 127-131.

Chen S., Yu, D., \& Wu, L-M. (2014). Fatigue risk fuzzy evaluation for high risk operations based on G1 method. Journal of Safety Science and Technology, 10 (04), 90-95.

Chen, S., Yu, D., \& Zheng, X-Z. (2014). Maturity Evaluation on Safety Standardization in Hydropower Construction: Methodology and Case Study. Engineering Letters, 22(4), 194-201.

Chen, S., Yu, D., Zheng, X-Z., \& Chen, A-H. (2014). Study on synergistic emergency response to major events. China Safety Science Journal, 24(1), 156-162.

Cheyne, A., Cox, S., Oliver A., \& Tomas, J.M. (1998). Modelling safety climate in the prediction of levels of safety activity. Work \& Stress, 12(3), 255-271.

http://dx.doi.org/10.1080/02678379808256865

Coyle, I.R., Sleeman, S.D., \& Adams, N. (1996). Safety climate. Journal of Safety Research, 26(4), 247-254. http://dx.doi.org/10.1016/0022-4375(95)00020-Q

Hale, A.R., Heming, B., Carthey J., \& Kirwan, B. (1997). Modelling of safety management systems. Safety Science, 26(1), 121-140. http://dx.doi.org/10.1016/S0925-7535(97)00034-9

Inoue, K., Gotoh, E., Ishigaki, I., \& Hasegawa, T. (1999). Factor analysis of risk-taking behavior in forest work. Journal of Forest Research, 4(3), 201-206. http://dx.doi.org/10.1007/BF02762249

Kath, L.M., Magley V.J., \& Marmet, M. (2010). The role of organizational trust in safety climate's influence on organizational outcomes. Accident Analysis \& Prevention, 42(5), 1488-1497. http://dx.doi.org/10.1016/j.aap.2009.11.010

Kirwan, B. (2007). Safety informing design. Safety Science, 45(1-2), 155-197. http://dx.doi.org/10.1016/j.ssci.2006.08.011 
Larsson, S., Pousette, A., \& Törner, M. (2008). Psychological climate and safety in the construction industry-mediated influence on safety behavior. Safety Science, 46(3), 405-412. http://dx.doi.org/10.1016/j.ssci.2007.05.012

Lu, C-S., \& Yang, C-S. (2011). Safety climate and safety behavior in the passenger ferry context. Accident Analysis \& Prevention, 43(1), 329-341.

http://dx.doi.org/10.1016/j.aap.2010.09.001

Matthews, R.A., Gallus, J.A., \& Henning R.A. (2011). Participatory ergonomics: Development of an employee assessment questionnaire. Accident Analysis \& Prevention, 43(1), 360-369. http://dx.doi.org/10.1016/j.aap.2010.09.004

Meyer, J.P., \& Allen, N.J. (1984). Testing the "side-bet theory" of organizational commitment: Some methodological considerations. Journal of applied psychology, 69(3), 372. http://dx.doi.org/10.1037/0021-9010.69.3.372

Neal, A., Griffin, M.A., \& Hart, P.M. (2000). The impact of organizational climate on safety climate and individual behavior. Safety Science, 34(1-3), 99-109. http://dx.doi.org/10.1016/S09257535(00)00008-4

O'Connor, P., O'Dea, A., Kennedy, Q., \& Buttrey S.E. (2011). Measuring safety climate in aviation: A review and recommendations for the future. Safety Science, 49(2), 128-138. http://dx.doi.org/10.1016/j.ssci.2010.10.001

Oliver, A., Cheyne, A., Tomas, J.M., \& Cox, S. (2002). The effects of organizational and individual factors on occupational accidents. Journal of Occupational and Organizational psychology, 75(4), 473-488. http://dx.doi.org/10.1348/096317902321119691

Pousette, A., Larsson, S., \& Törner, M. (2008). Safety climate cross-validation, strength and prediction of safety behavior. Safety Science, 46(3), 398-404.

http://dx.doi.org/10.1016/j.ssci.2007.06.016

Probst, T.M., \& Estrada, A.X. (2010). Accident under-reporting among employees: Testing the moderating influence of psychological safety climate and supervisor enforcement of safety practices. Accident Analysis \& Prevention, 42(5), 1438-1444.

http://dx.doi.org/10.1016/j.aap.2009.06.027

Rundmo, T. (2000). Safety climate, attitudes and risk perception in Norsk Hydro. Safety Science, 34(1-3), 47-59. http://dx.doi.org/10.1016/S0925-7535(00)00006-0

Varonen, U., \& Mattila, M. (2000). The safety climate and its relationship to safety practices, safety of the work environment and occupational accidents in eight wood-processing companies. Accident Analysis \& Prevention, 32(6), 761-769. http://dx.doi.org/10.1016/S00014575(99)00129-3 
Vinodkumar, M.N., \& Bhasi, M. (2010). Safety management practices and safety behaviour: Assessing the mediating role of safety knowledge and motivation. Accident Analysis \& Prevention, 42(6), 2082-2093. http://dx.doi.org/10.1016/j.aap.2010.06.021

Vinodkumar, M.N., \& Bhasi, M. (2011). A study on the impact of management system certification on safety management. Safety Science, 49(3), 498-507.

http://dx.doi.org/10.1016/j.ssci.2010.11.009

Vredenburgh, A.G. (2002). Organizational safety: which management practices are most effective in reducing employee injury rates? Journal of safety Research, 33(2), 259-276. http://dx.doi.org/10.1016/S0022-4375(02)00016-6

Yule, S., Flin, R., \& Murdy, A. (2007). The role of management and safety climate in preventing risk-taking at work. International Journal of Risk Assessment and Management, 7(2), 137-151. http://dx.doi.org/10.1504/IJRAM.2007.011727

Zheng, X-Z., Chen, Q-L., Chen, S., \& Hu, B-F. (2011). Safety Assessment Method for Hydropower Construction Based on Rough Set. China Safety Science Journal, 21(1), 82-86.

Journal of Industrial Engineering and Management, 2015 (www.jiem.org)

Article's contents are provided on a Attribution-Non Commercial 3.0 Creative commons license. Readers are allowed to copy, distribute and communicate article's contents, provided the author's and Journal of Industrial Engineering and Management's names are included. It must not be used for commercial purposes. To see the complete license contents, please visit http://creativecommons.org/licenses/by-nc/3.0/. 